\title{
INACCURACY OF DICTION IN ARRANGEMENTS BY CLASS VII STUDENTS OF DAAR EL ARQAM MAUK ISLAMIC MIDDLE SCHOOL
}

\author{
Ahmad Hidayatullah*) \\ Universitas Muhammadiyah Bandung \\ Nini Ibrahim \\ Universitas Muhammadiyah Prof. DR.Hamka \\ Fauzi Rahman \\ Universitas Indraprasta PGRI \\ Ahmad Muzaki \\ Universitas Indraprasta PGRI \\ *) Correspondences author: Jalan Raya Mauk, Kp. Pasar Sore RT07/02, Mauk, 15530, Indonesia; \\ e-mail: ahidayatullah62@yahoo.com
}

\begin{abstract}
Diction is the most important aspect in determining sentence clarity. Through diction, a person can develop ideas in his descriptive essay. Therefore, the purpose of this study was to examine the inaccuracy of diction in students' descriptive essays, and to describe the results of the research as learning materials. This research method is a qualitative description method. This research was conducted by analyzing students' descriptive essays based on the inaccuracy of diction in the sentences used. The results of this study indicate that there are students' inaccuracies in using diction, namely 53 inaccuracy of diction based on lexical meaning, 34 grammatical meanings, 12 use of synonyms, and 4 uses of denotation and connotation. The conclusion in this study is that the students' ability to use diction has not been properly used in the descriptions they made.
\end{abstract}

Keywords: Inaccuracy, Diction, Arrangements

Article History: Received: 04/06/2021; Revised: 09/06/2021; Accepted: 10/06/2021; Published: 30/06/2021.

How to Cite (MLA $7^{\text {th }}$ ): Hidayatullah, Ahmad, et al. "Inaccuracy of Diction in Arrangements by Class VII Students of Daar El Arqam Mauk Islamic Middle School." Hortatori: Jurnal Pendidikan Bahasa dan Sastra Indonesia 5.1 (2021): 1-7. Print/Online. Copyrights Holder: Ahmad Hidayatullah, Nini Ibrahim, Fauzi Rahman, Ahmad Muzaki. First Publication: Hortatori: Jurnal Pendidikan Bahasa dan Sastra Indonesia (2017).

\section{Pendahuluan}

Melihat perkembangan Kurikulum 2013, materi bahasa Indonesia dikembangkan melalui beberapa pendekatan, salah satunya pendekatan berbasis teks (Tenesia dan Andria 202). Pembelajaran berbasis teks ini dikembangkan melalui kegiatan menulis. Dengan menulis, siswa dapat mengeksplorasi perasaan dan pikirannya secara bebas dengan memperhatikan kaidah bahasa yang berlaku (Yodeska dan Nursaid 517; Fahriaty, 2013).

Salah satu kegiatan menulis teks tersebut ialah menulis karangan deskripsi. Karangan deskripsi dapat diartikan sebagai teks yang menuangkan suatu pelukisan atau penggambaran suatu hal atau kejadian agar pembaca dapat merasakan dan memberikan kesan yang menarik sesuai dengan yang ditulis. (Tenesia dan Andria 203; Hasibuan, 2017; Aswat 2019). Dengan kata lain, karangan deskripsi ini menceritakan suatu kejadian dengan memberikan pelukisan dengan jelas kepada pembaca agar dapat merasakan kejadian tersebut.

Dalam karangan deskripsi, penulis memerlukan kecermatan dan ketelitian (Elen, 2017). Dengan kecermatan, penulis dapat mengembangkan bagian-bagian kejadian melalui rangkaian kata yang tepat 
untuk memperoleh kesan yang menarik, sehingga pembaca mampu menikmati setiap pelukisan atau penggambaran cerita yang dibuat. Pada sisi lain, agar menghasilkan gambaran yang diharapkan tersebut, dibutuhkan juga ketelitian dalam menggunakan diksi (rangkaian pilihan kata) untuk menopang tujuan karangan deskripsi.

Untuk mendapatkan lukisan atau gambaran cerita yang menarik, diperlukan diksi yang tepat dan dapat mewakili setiap bagian-bagian gagasan yang hendak ditulis (Tenesia dan Andria 203). Diksi dapat menentukan kualitas karangan deskripsi, sebab diksi merupakan salah satu aspek terpenting dalam menentukan kejelasan kalimat. Melalui diksi, seseorang dapat mengungkapkan dan mengembangkan gagasan, ide, atau perasaan yang terorganisasi dalam tulisan maupun lisan (Asmara et al. 2018). Untuk itu, diksi yang digunakan harus mampu mewakili gagasan secara tepat.

Penggunaan diksi menyangkut persoalan yang bukan sederhana. Diksi memiliki potensi dalam menentukan dan membedakan makna secara tepat berdasarkan gagasan atau segala sesuatu yang ingin diungkapkan berdasarkan posisi atau bentuk kata dalam kalimat (Nufrianti et al. 222: Purwaningsih, 2012). Dengan demikian, sudah jelas bahwa melalui diksi yang digunakan akan menentukan ketepatan makna gagasan seseorang secara tepat.

Diksi diarahkan pada kata-kata atau penggunaan pilihan kata yang tepat (Purwaningsih, 2012; Hardianto, 2017). Tepat artinya kemampuan dalam mengungkapkan makna melalui diksi yang dipilihnya (Halimatussakdiah dan Grace, 2013). Hal ini sesuai dengan pendapat Keraf dalam Madu (267), ketepatan diksi dapat diukur dengan baik jika dapat menimbulkan imajinasi pembaca terhadap apa yang dibacanya. Gani (130) menerangkan, diksi juga dapat diartikan sebagai kegiatan menyeleksi kata-kata sedemikian rupa dalam rangka mengekspresikan ide, gagasan, atau perasaan. Dengan demikian, diksi dapat diartikan sebagai kemampuan atau kesanggupan sebuah kata dalam menimbulkan dan mengungkapkan makna berdasarkan gagasan atau ide yang disampaikan.

Diksi dapat dijadikan sebagai acuan dalam menulis karangan (Nufrianti et al. 222). Melalui diksi, terbentuk kalimat-kalimat efektif yang dapat mewakili gagasan atau ide secara tepat. Kumpulan-kumpulan kalimat tersebut, terorganisir dan tersusun menjadi paragraf dan kumpulan paragraf hingga tersusunnya karangan dengan baik. Hal inilah yang membuat diksi penting untuk dipelajari dan dikaji, khususnya dalam mengolah kemampuan diksi siswa dalam menulis karangan deskripsi (Madu 267).

Penelitian terdahulu tentang penggunaan diksi pada karangan deskripsi ini pernah dilakukan oleh Tenesia dan Andria (2019) dengan judul Diksi dalam Teks Deskripsi Siswa Kelas VII SMP Negeri 11 Padang dengan metode deskriptif. Hasil penelitian tersebut terbatas pada simpulan bahwa penggunaan diksi lebih banyak muncul dalam teks deskripsi siswa ini yaitu ketepatan, kecermatan, dan keserasian. Pada sisi lain, siswa masih mengalami kesulitan dalam menulis teks deskripsi, khususnya kesulitan dalam memilih dan menggunakan pilihan kata, serta ejaan bahasa Indonesia.

Melihat penelitian Tenesia dan Andria (2019), tentunya penelitian tersebut relevan dengan penelitian yang sedang dijalankan oleh penulis. Dalam penelitian ini, fokus penelitian sama-sama diarahkan ke kelas VII SMP sesuai dengan kurikulum 2013 terkait materi karangan deskripsi. Akan tetapi, penelitian terdahulu baru sebatas pemaparan umum saja, hanya sebatas analisis ketepatan dan ketidaktepatan diksi yang dikaji. Dalam penelitian ini, selain mengkaji atau menganalisis ketidaktepatan diksi, penulis juga membuat klasifikasi jenis ketidaktepatan diksi dalam bebrapa kategori dan melanjutkan hasil penelitian ini sebagai sumber bahan belajar siswa.

Diksi juga dapat dijadikan sebagai acuan membuat karangan deskripsi. Dalam karangan deskripsi, diksi yang digunakan harus tepat agar memiliki gambaran yang tepat sesuai dengan tujuan yang disampaikan. Namun, siswa masih mengalami kerumitan dalam menggunakan diksi pada karangan deskripsi yang dibuatnya. Diketahui pula, siswa mengalami kesulitan dalam mengolah dan mengorganisasikan ide atau gagasannya dalam karangan deskripsi serta siswa mengalami kesulitan dalam menentukan diksi (pemilihan kata) yang tepat saat menulis karangan deskripsi atau masih terdapat ketidaktepatan diksi atau kesalahan dalam menggunakan diksi yang belum tepat (Tenesia dan Andria 204).

Melihat fenomena di atas, penulisan karangan deskripsi mengenai penggunaan diksi siswa perlu mendapati perhatian khusus. Diksi dalam kalimat harus dipilih dan digunakan secara tepat, sebab dengan ketidaktepatan diksi dalam kalimat akan mengacaukan atau mengaburkan makna kalimat atau pesan informasi yang disampaikan dalam karangan deskripsi. Dengan demikian, agar pesan atau informasi yang ingin disampaikan dalam karangan deskripsi tersebut dapat diterima, maka diksi yang digunakan harus tepat dan tidak mengalami kesalahan atau penyimpangan ketidaktepatan diksi. 
Fenomena yang di uraikan di atas, menunjukkan adanya masalah dalam karangan deskripsi siswa yaitu penggunaan diksi yang tidak tepat atau ketidaktepatan diksi dalam karangan deskripsi yang dibuat siswa. Ketidaktepatan diksi sering terjadi dalam mengungkapkan makna dalam suatu kalimat. Masalah ketidaktepatan diksi ini terjadi dalam seputar pemilihan dan penggunaan kata yang belum tepat dengan maknanya, baik secara makna leksikal-gramatikal maupun denotasi dan konotasi. Ketidaktepatan diksi terjadi juga dalam penggunaan kata sinonim dan antonym, serta dalam penggunaan variasi majas (Nufrianti, et al. 222).

Masalah ketidaktepatan diksi diperjelaskan kembali oleh Madu (269) bahwa ketidaktepatan diksi menyangkut masalah ketidaktepatan diksi pada sinonim; ketidaktepatan penggunaan kata aktif, pasif, kata depan, dan kata yang tidak sesuai konteks kalimat; ketidaktepatan diksi karena kesalahan penggunaan partikel dan proses afiksasi; ketidaktepatan diksi pada kata khusus dan umum serta pada perubahan makna kata.

Berdasarkan uraian tersebut, penting dilakukan penelitian untuk mengkaji ketidaktepatan diksi siswa kelas VII SMP Islam Daar El Arqam Mauk. Hal ini dimaksudkan agar selaras dengan tujuan penelitian ini yaitu untuk mengkaji proses ketidaktepatan diksi dalam karangan deskripsi siswa, serta mendeskripsikan hasil temuan ketidaktepatan diksi tersebut untuk dijadikan sebagai bahan pembelajaran siswa.

\section{Metode}

Metode dalam penelitian ini yaitu metode deskripsi kualitatif. Metode ini dilakukan dengan memaparkan data faktual secara deskripsi dan sistematik berdasarkan temuan-temuan nyata dengan menganalisis data secara objektif (Chaer, 2011:9). Penelitian ini dilakukan dengan menganalisis karangan deskripsi siswa berdasarkan ketidaktepatan diksi yang digunakan dalam kalimat-kalimat yang digunakan. Subjek dalam penelitian ini ialah siswa kelas VIIA yang berjumlah 33 siswa. Data yang digunakan yaitu hasil karangan deskripsi yang dibuat siswa, sedangkan sumber datanya yaitu kumpulan kata (kalimatkalimat) yang digunakan siswa dalam membuat karangan deskripsi.

Prosedur dalam penelitian ini dimulai dengan mendapati data yaitu karangan deskripsi yang dibuat siswa kelas VII. Karangan tersebut dibaca dan dianalisis, serta diklasifikasi berdasarkan kategori ketidaktepatan diksi. Analisis data dilakukan dengan beberapa tahap, seperti data yang telah direduksi kemudian dianalisis, dideskripsikan, diperbaiki dan dijelaskan apabila terdapat data yang tidak tepat. Hasil analisis tersebut, akan diketahui seberapa tinggi kemampuan siswa dalam memilih dan menggunakan kata secara tepat. Selanjutkan hasil analisis tersebut diberikan interprestasi berdasarkan temuan-temuan penelitian dan diakhiri dengan membuat simpulan.

\section{Hasil dan Diskusi}

Berdasarkan analisis data dapat diketahui bahwa karangan deskripsi siswa Kelas VII SMP Islam Daar El Arqam mauk masih mengandung ketidaktepatan diksi dalam mengungkapkan makna gagasan. Hal dapat diketahui dari hasil analisis yang penulis rangkum dalam tabel berikut ini.

Tabel 1. Analisis Ketidaktepatan Diksi Pada Karangan Deskripsi

\begin{tabular}{|c|c|c|c|}
\hline No & Ketidaktepatan Diksi & Jumlah Analisis & Keterangan \\
\hline 1 & Segi Makna Leksikal & 53 buah & Arti makna kamus \\
\hline 2 & Segi Gramatikal & 34 buah & Pengimbuhan, pengulangan, dan pemajemukan \\
\hline 3 & Sinonim & 12 buah & Kemiripan makna \\
\hline 4 & Denotasi dan Konotasi & 4 buah & Positif dan negatif \\
\hline
\end{tabular}

Berdasarkan hasil di atas, diketahui terdapat beberapa kesalahan atau ketidaktepatan siswa dalam menggunakan diksi. Ketidaktepatan siswa dalam menggunakan diksi yang terdapat dalam karangan deskripsi yang dibuatnya meliputi ketidaktepatan diksi dalam mengungkapkan makna berdasarkan segi makna leksikal, makna gramatikal, dan penggunaan kata sinonim serta penggunaan denotasi dan konotasi.

\section{Ketidaktepatan Diksi Berdasarkan Makna Leksikal}

Ketidaktepatan diksi dari segi makna leksikal terdapat di dalam karangan deskripsi siswa kelas VII sebanyak 53 kata. Berdasarkan analisis karangan deskripsi siswa tersebut, ditemukan beberapa kalimat yang di dalamnya mengandung ketidaktepatan kata, yaitu salah satunya terdapat dalam kalimat: 


\section{[1] Letak rumahku terdapat di samping lapangan dan saya senang bermain di sana.}

Dalam kalimat [1] di atas, terdapat kata yang memiliki kesalahan dalam makna leksikal, yaitu pada kata terdapat. Kata yang lebih tepat digunakan yaitu berada. Dalam Kamus Besar Bahasa Indonesia, kata terdapat artinya diperoleh; didapati; ditemukan; sedangkan berada merupakan ada; berpunya. Kalimat dalam teks tersebut menjelaskan keberadaan sebuah tempat, sehingga kata yang lebih tepat digunakan yaitu berada, karena kata berada menandakan suatu letak keberadaan atau kepemilikan akan suatu hal, dalam hal ini letak rumah.

Arti kata berada yang dijelaskan di atas, sudah mengandung makna leksikal yang tepat sesuai dengan makna sebenarnya atau makna kamus. Hal ini dipertegas oleh Rahmawati dan Nurhamidah (2018), makna leksikal dapat diartikan sebagai makna kata berdasarkan kamus. Dengan kata lain, makna leksikal dianggap sejajar dengan arti denotatif dan terlepas dari konteks.

\section{Ketidaktepatan Diksi Berdasarkan Makna Gramatikal}

Ketidaktepatan diksi dari segi makna gramatikal terdapat di dalam karangan deskripsi siswa sebanyak 34 kata, yaitu salah satunya terdapat dalam kalimat:

[2] Setelah di pukul, Roni pulang tanpa dosa. Kasihan Ridwan kesakitan, Roni memang nakal. Besoknya, saya lapor ke walikelasnya.

Dalam kalimat [2] di atas terdapat kata yang memiliki kesalahan dalam penulisan gramatikal, yaitu pada kata di pukul dan walikelasnya. Pada kata di pukul dianggap salah penulisannya, karena kata yang lebih tepat digunakan yaitu kata memukul. Karena penulisan kata akan menentukan fungsi gramatikal atau proses pembentukan kata yang pada akhirnya menentukan makna yang berbeda pula. Kata dipukul dengan memukul memiliki makna yang berbeda. Kata dipukul memiliki makna dikenai suatu pukulan dari orang lain, sedangkan kata memukul memiliki makna mengenai suatu pukulan ke orang lain. Dalam kalimat tersebut menerangkan bahwa Roni telah melakukan pemukulan kepada Ridwan, bukan Ridwan yang melakukan pemukulan ke Roni. Agar dalam kalimat tersebut tidak mengalami ketidaktepatan diksi maka kata dipukul diganti dengan memukul.

Hasil analisis ini dipertegas Chaer (2011), fungsi imbuhan $m e$ - dan $d i$-adalah memiliki fungsi yang berbeda. Jika imbuhan me- membentuk kata kerja transitif, sedangkan imbuhan $d i$ - membentuk kata kerja intransitif.

Dalam kalimat [2] di atas juga terdapat kata yang memiliki kesalahan dalam penulisan, yaitu pada kata walikelasnya. Kata yang lebih tepat digunakan yaitu wali kelasnya. Penulisan kata wali kelas harus dipisah, sebab terdiri atas dua kata yang tidak terikat (pemajemukan). Sriyanto (33) mengatakan penulisan terkait gabungan kata antara satu dengan lain telah diatur di Pedoman Umum Ejaan Bahasa Indonesia yang Disempurnakan (PUEBI). Seperti halnya kata wali kelas, terdapat gabungan kata terikat dan kata tidak terikat. Kata wali merupakan unsur terikat, sedangkan kata kelas bukan unsur terikat, namun penulisannya tetap dipisah.

Proses pembentukan yang dijelaskan di atas, disebut dengan proses makna gramatikal. Arti kata ini timbul akibat adanya hubungan kata dengan kata lain (Rahmawati dan Nurhamidah, 2018; Chaer, 2011). Dengan kata lain, makna gramatikal disebut dengan makna yang sesuai dengan konteks yang digunakannya sebagai wujud pembentukan gramatikal, seperti imbuhan (afiksasi), kata ulang (reduplikasi), dan kata majemuk (Hutri, 2020; Nursianti, 2016; Jannah, 2020; Kayep, 2018).

\section{Ketidaktepatan Diksi Berdasarkan Penggunaan Kata Sinonim}

Ketidaktepatan diksi dari segi penggunaan sinonim terdapat dalam karangan deskripsi sebanyak 12 kata, yaitu salah satunya terdapat dalam kalimat:

[3]Aku senang dan gembira, karena orang tuaku sangat sayang padaku.

Dalam kalimat [3] di atas, terdapat kata yang memiliki kesalahan dalam penggunaan kata sinonim, yaitu pada kata senang dan gembira. Kata senang bermakna suka; gembira; berbahagia, sedangkan kata gembira bermakna suka; bahagia; bangga. Kata senang; gembira ini mempunyai makna yang sama. Agar tidak menimbulkan kata mubazir, maka sebaiknya tidak menggunakan gabungan kata yang memiliki makna yang sama, cukup satu kata yang dipakai (Nursyamsi 113). Hal ini terjadi akibat dari tumpang tindihnya penggunaan sinonim dalam kalimat. 


\section{Ketidaktepatan Diksi Berdasarkan Penggunaan Denotasi dan Konotasi}

Ketidaktepatan diksi dari segi penggunaan denotasi dan konotasi juga terdapat di dalam karangan deskripsi siswa. Salah satunya terdapat dalam kalimat:

\section{[4]Sekolahanku terdapat 3 WC, 1 WC untuk guru, dan 2 WC untuk siswa.}

Dalam kalimat [4] di atas, terdapat kata yang memiliki kesalahan dalam penggunaan kata denotasi dan konotasi, yaitu pada kata $\underline{W C}$. Pemilihan kata $\underline{W C}$ dalam kalimat tersebut, dianggap memiliki konotasi negatif. Kata $W C$ terkesan kasar berbeda jika menggunakan kata toilet. Toilet merupakan tempat cuci tangan dan muka, serta kamar kecil (kakus). Penggantian kata toilet ini sudah lebih baik dan lebih tepat sebab sudah sesuai dengan maksud kalimat tersebut yang menerangkan fasilitas kamar kecil di sekolah.

Berdasarkan hasil analisis di atas, dapat memberikan gambaran ketidaktepatan diksi yang paling banyak terjadi (muncul) pada karangan deskripsi siswa yaitu lebih banyak mengalami ketidaktepatan diksi dalam mengungkapkan makna leksikal. Disusul dengan ketidaktepatan diksi lainnya berdasarkan makna gramatikal, penggunaan sinonim, dan penggunaan denotasi dan konotasi.

Dalam memilih kata yang tepat, dapat ditandai dengan penggunaan kata yang lugas daan tidak bertele-tele sehingga gagasan atau pikiran dapat dituangkan dengan tepat (Nursyamsi, 2016). Dengan pilihan kata yang tepat dapat menghasilkan pesan atau informasi yang tepat kepada pembaca atau pendengar, baik secara tulisan maupun lisan (Mustakim, 2016; Nursyamsi 49). Sebaliknya, jika tidak memperhatikan ketepatan diksi, maka karangan deskrispsi yang dibuat siswa akan mengalami ketidaktepatan diksi dalam kalimat-kalimat yang disusunnya.

Ketidaktepatan siswa dalam menggunakan diksi dapat terjadi dari segi makna leksikal. Ketidaktepatan diksi dapat mengaburkan makna dari kata itu sendiri (makna leksikal) sebab makna leksikal ini dapat berdiri sendiri tanpa harus ada kaitan dengan kata lainnya (Rahmawati dan Nurhamidah, 2018; Kayep, 2018). Penggunaan diksi yang tepat akan menimbulkan kesadaran penulis dalam memilah dan memilih kata, sebab akan mempengaruhi kemampuan dalam pembendaharaan kata yang dimiliki penulis sendiri.

Ketidaktepatan diksi siswa dapat terjadi dari segi makna gramatikal. Makna gramatikal berbeda dengan arti makna leksikal. Makna gramatikal timbul sebagai hasil dari proses afiksasi, reduplikasi, dan kata majemuk (Hutri, 2020; Kayep, 2018). Proses grmatikal ini harus berjalan dengan tepat agar dapat menghindari kesalahpahaman atau ketidaktepatan diksi penulis. Untuk itu, penulis harus menguasai diksi dan meningkatkan kosakatanya.

Ketidaktepatan siswa dalam menggunakan diksi dapat terjadi dari segi penggunaan kata sinonim. Seorang penulis harus cermat dalam memilih kata yang bersinonim dalam mengungkapkan pikirannya dengan tepat. Penggunaan kata sinonim kerap sekali terjadi kesalahan, sebab kata bersinonim tidak selalu dapat menggantikan kata lain yang mirip (Kayep, 2018). Meski, kata yang digunakan tersebut dianggap bersinonim, namun tetap saja harus memperhatikan konteks dan tujuan kalimat itu sendiri. Kata yang bersinonim pun harus dapat mewakili pikiran penulis, agar tujuan penulis dapat diinterpretasikan dengan baik.

Ketidaktepatan siswa dalam menggunakan diksi dapat terjadi dari segi penggunaan kata denotasi dan konotasi. Penggunaan kata denotasi dan konotasi digunakan untuk menimbulkan reaksi emosional pembaca agar makna yang disampaikan dapat ditangkap oleh pembaca (Kayep, 2018). Karangan deskripsi yang dibuat siswa sebagian besar menimbulkan ketidaktepatan diksi dari segi denotasi dan konotasi yang tidak tepat. Hal ini timbul sebagai akibat kurangnya pemahaman siswa, khususnya dalam membedakan makna konotasi positif dan makna konotasi negatif.

Seiring berkembangnya ilmu pengetahuan dan teknologi, materi karangan deskripsi dan penggunaan diksi pun perlu selalu melakukan pembaharuan materi yang disesuaikan dengan perkembangan zaman. Salah satunya dapat dilihat dari bahan ajar yang digunakan dalam belajar. Bahan ajar yang digunakan akan berkembang dan semakin bervariasi. Untuk itu, diperlukan upaya guru dalam mengimbangi bahan ajar tersebut agar materi dapat disampaikan dengan baik kepada siswa. Di samping itu, guru juga harus lebih berinovasi menggunakan bahan pelajaran.

Hasil pembelajaran bahasa Indonesia siswa, harus tercapai dengan baik, khususnya dalam kemampuan menulis karangan deskripsi siswa melalui sumber belajar atau bahan ajar yang digunakan. Pemanfaatan sumber belajar atau bahan ajar ini harus disesuaikan dengan indikator pembelajaran bahasa Indonesia yang sudah ditetapkan. Untuk itu, guru dituntut untuk cermat dalam memilih sumber belajar yang digunakan. 
Melalui kegiatan menulis karangan deskripsi, siswa dapat meningkatkan kemampuan menulis dan pembendaharaan kata dengan baik. Hal ini tentunya dapat tercapai, apabila guru mampu memilih dan menggunakan bahan dan sumber ajar yang tepat. Selain praktis dan fleksibel, bahan dan sumber ajar yang digunakan haruslah bersifat ekonomis dan mudah didapat agar siswa dapat memperoleh dan mempelajarinya dengan mudah. Materi dalam bahan ajar pun harus mencerminkan tujuan pendidikan dan tersusun sesuai dengan tatanan kebahasaan yang benar, khususnya dalam penggunaan diksi yang tepat. Hal ini tentunya diperhatikan agar karangan deskripsi siswa dapat tersusun dengan baik dan sudah tepat, khususnya dalam menggunakan diksi (Nufrianti, et al. 224-225).

\section{Simpulan}

Karangan deskripsi siswa kelas VII SMP Islam Daar El Arqam Mauk masih mengalami penyimpangan dalam penggunaan diksi, dalam hal ini yaitu ketidaktepatan diksi. Ketidaktepatan diksi tersebut terjadi dalam mengungkapkan makna berdasarkan ketidaktepatan diksi dari segi makna leksikal, makna gramatikal, dan penggunaan kata sinonim serta penggunaan denotasi dan konotasi. Hal ini membuktikan kemampuan penggunaan diksi siswa belum tepat digunakan dalam karangan deskripsi yang dibuatnya.

Temuan-temuan hasil penelitian ini diharapkan menjadi perhatian bagi guru dan siswa. Guru harus lebih meningkatkan lagi teknik dan metode dalam mengajarkan atau memberikan materi tentang menulis karangan deskripsi, khususnya dalam penggunaan diksi. Sedangkan, siswa harus mengembangkan kemampuan menulis karangan deskripsinya, mampu memilah, memilih, dan menggunakan kata dengan tepat, serta mampu mengetahui makna yang digunakannya.

Saran yang dapat diajukan terkait temuan hasil penelitian ini yaitu 1)siswa harus meningkatkan kemampuan membaca dengan baik, agar pembendaharaan katanya dapat meningkat; 2)siswa harus sering berlatih menulis karangan, khususnya karangan deskripsi agar mampu memahami teknik penyusunan karangan dengan baik; 3)guru harus ikut andil dalam meningkatkan kemampuan siswa dalam menulis, khususnya mengajarkan dan mengembangkan kemampuan siswa dalam menulis karangan melalui diksi yang tepat; 4)guru harus melakukan evaluasi terhadap karangan siswa yang dibuatnya, serta melakukan perbaikan pengajaran menulis berdasarkan hasil evaluasi yang dilakukan.

\section{Ucapan Terima Kasih}

Ucapan terima kasih penulis sampaikan kepada Prof. Dr. H. Suyatno, M.Pd., selaku Rektor Universitas Muhammadiyah Bandung atas izin dan arahan dalam penelitian ini. Ucapan terima kasih juga penulis sampaikan kepada Tim Editorial Jurnal Hortatori atas kesempatan menerbitkan artikel di jurnal ini. Semoga Jurnal Hortatori semakin maju.

\section{Daftar Rujukan}

Asmara, Rangga, and Widya Ratna Kusumaningrum. "Pembongkaran Puitik terhadap Diksi-Diksi Gender dalam Sajak-Sajak Dorothea: Kontra Hegemoni Dunia Penciptaan Kaum Lelaki." Jurnal Poetika 6.1 (2018): 1-12.

Aswat, Hajratul, et al. "Pembelajaran Menulis Karangan Deskripsi Menggunakan Media Gambar." (2019). Chaer, Abdul. Ragam Bahasa Ilmiah. Jakarta: Rineka Cipta. (2011).

Elen, Enjelina Dedek. Kemampuan Memahami Jenis Reduplikasi dalam Teks Deskriptif oleh Siswa Kelas XI SMK Marisi Medan Tahun Pelajaran 2016/2017. Diss. UNIMED. (2017).

Fahriaty, Eti. "Peningkatan Kemampuan Menulis Puisi Melalui Penerapan Strategi Sugestopedia." International Seminar on Quality and Affordable Education 2.2 (2013).

Gani, Erizal. Bahasa Karya Tulis Ilmiah. UNP PRESS. (2012).

Halimatussakdiah, Halimatussakdiah, and Grace Situmorang. "Penggunaan Diksi dalam Penulisan Makalah Pada Mahasiswa Jurusan Pendidikan Akuntansi." School Education Journal PGSD FIP Unimed 1.1. (2017).

Hardianto, Musa, Wahyu Widayati, and Sucipto Sucipto. "Diksi dan Gaya Bahasa Pada Naskah Pidato Presiden Soekarno." Jurnal Ilmiah Fonema: Jurnal Edukasi Bahasa dan Sastra Indonesia 4.2 (2017). 
Hutri, Kemala, Deliana, and Khairina Nasution. "Bentuk dan Makna Reduplikasi Adjektiva dalam Bahasa Minangkabau Dialek Sungayang di Kab. Tanah Datar." Jurnal Humanika 27.2 (2020): 95-104.

Jannah, Miftachul. "Afiksasi (Prefiks dan Sufiks) dalam Kolom Ekonomi Bisnis Di Koran Jawa Pos Edisi Kamis 14 November 2019." Jurnal Disastri (Jurnal Pendidikan Bahasa dan Sastra Indonesia) 2.1 (2020): 18-25.

Madu, Fransiska Jaiman. "Diksi Pada Teks Narasi Siswa Sekolah Dasar." Jurnal Pendidikan dan Kebudayaan Missio 7.2 (2015): 267-272.

Hasibuan, Sefrida. "Meningkatkan Kemampuan Menulis Karangan Deskripsi dengan Metode Latihan Terbimbing Menggunakan Gambar di SMAN 4 Pekanbaru." GERAM 5.2 (2017): 1-6.

Mustakim. Bentuk dan Pilihan Kata. Jakarta: Badan Pengembangan dan Pembinaan Bahasa, Kemendikbud (2016).

Nufrianti, Surianjani, Ria Ariesta, and Rio Kurniawan. "Penggunaan Diksi dalam Karangan Narasi Fantasi Siswa Kelas VII SMPN 13 Kota Bengkulu." Jurnal Korpus 3.2 (2019): 221-227.

Nursianti, Biata. "Pengulangan Kata dalam Bahasa Dayak Seberuang di Sekubang, Kecamatan Sepauk, Kalimantan Barat." Sintesis 10.2 (2016): 113-123.

Nursyamsi. Ketidaktepatan Penggunaan Diksi dalam Teks Berita "Lintas Sulteng” Di Tvri Kota Palu. Jurnal Multilingual. 17 (2016): 106-116.

Purwaningsih. Jenis Kalimat dan Diksi dalam Ucapan Selamat Idul Fitri 1432 H Melalui Short Message Service (SMS). Disertasi. Universitas Muhammadiyah Surakarta. (2012).

Rahmawati, Nur, and Didah Nurhamidah. "Makna Leksikal dan Gramatikal Pada Judul Berita Surat Kabar Pos Kota (Kajian Semantik)." JURNAL SASINDO UNPAM. 6.1 (2018): 39-54.

Sriyanto. Ejaan. Jakarta: Kementrian Pendidikan dan Kebudayaan. (2015).

Tenesia, Tevani, and Andria Catri Thamsin. "Diksi dalam Teks Deskripsi Siswa Kelas VII SMP Negeri 11 Padang." Pendidikan Bahasa Indonesia. 8.1 (2019): 202-213.

Yodeska, Yolla Karchia, and Nursaid Nursaid. "Struktur Kalimat dan Diksi Teks Eksposisi Karya Siswa Kelas VII SMP Negeri 12 Padang." Pendidikan Bahasa Indonesia. 8.3 (2020): 517-525. 